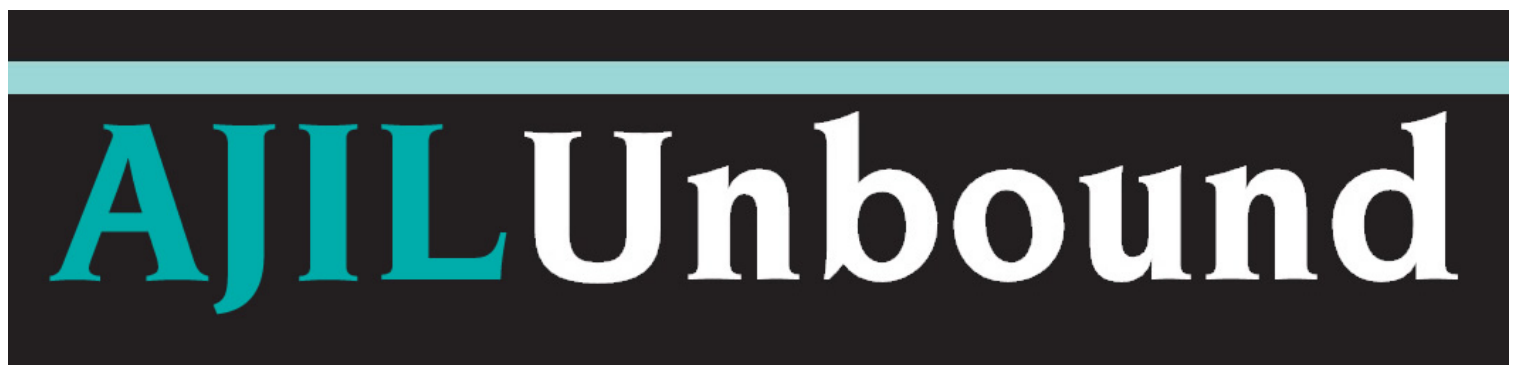

VOL. 109

July 2015-May 2016

CONTENTS

PAGE

\title{
Agora: Reflections on Zivotofsky v. Kerry
}

Introduction to Agora: Reflections on Zivotofsky v. Kerry

Curtis A. Bradley \& Carlos M. Vázquez 1

Historical Gloss, the Recognition Power, and Judicial Review

Zivotofsky II's Two Visions for Foreign Relations Law Curtis A. Bradley 2

Harlan Grant Cohen

Zivotofsky v. Kerry and the Balance of Power

Normalizing Foreign Relations Law after Zivotofsky II

Jean Galbraith $\quad 16$

Peter J. Spiro $\quad 22$

Introduction to Agora, Part II: Reflections on Zivotofsky v. Kerry

Curtis A. Bradley \& Carlos M. Vázquez 44

Zivotofsky: The Difference Between Inherent and Exclusive

Presidential Power Julian Davis Mortenson

Presidential Signing Statements and Dialogic Constitutionalism Catherine Powell 51

Zivotofsky and the Politics of Passports

Speaking With One Voice on the Recognition of States

\section{Symposium on Stavros Gadinis}

Introduction to Symposium on Stavros Gadinis, "Three Pathways to

Global Standards: Private, Regulator, and Ministry Networks"

$$
\text { Tom Ginsburg } 28
$$

Enter the Fox-Lumping and Splitting in the Study of Transnational

Networks: A Response to Stavros Gadinis $\quad$ Robert B. Ahdieh 29

Standards, Networks, and the Political Economy of International

$$
\text { Lawmaking: A Response to Stavros Gadinis Paul B. Stephan }
$$

Starting and Stopping Points: A Response to Stavros Gadinis 


\section{Symposium: Rethinking State Jurisdiction in the Internet Era}

Introduction to Symposium: Rethinking State Jurisdiction in the Internet Era Tom Ginsburg

A New Jurisprudential Framework for Jurisdiction: Beyond the Harvard Draft: Comment on "A New Jurisprudential Framework for Jurisdiction" Dan Jerker B. Svantesson

A Private (International) Law Perspective: Comment on "A New Jurisprudential Framework for Jurisdiction" Horatia Muir Watt An Urgent Suggestion to Pour Old Wine Into New Bottles: Comment on

"A New Jurisprudential Framework for Jurisdiction" Cedric Ryngaert

Comment on Svantesson, A New Jurisprudential Framework for Jurisdiction Tom Ginsburg

Symposium on the Constitutionalization of International Law in Latin America Introduction to Symposium on the Constitutionalization of International Law in Latin America Alexandra Hunees

Conventionality Control: The New Doctrine of the Inter-American Court of Human Rights Eduardo Ferrer Mac-Gregor

An Alternative Approach to the Conventionality Control Doctrine

Ius Constitutionale Commune en América Latina: Observations on Ariel E. Dulitzky

Transformative Constitutionalism Armin von Bogdandy

Democracy and Rights in Gelman v. Uruguay

$$
\text { Roberto Gargarella }
$$

Symposium: The Pope's Encyclical and Climate Change Policy

Introduction to Symposium: The Pope's Encyclical and Climate Change Policy

Theology and Politics in Laudato Si'

Dale Jamieson

Should We Care What The Pope Says About Climate Change?

Dominion and Stewardship

$$
\text { Daniel Bodansky }
$$

Dinah Shelton

Laudato Si', Pope Francis' Call to Ecological Conversion,

Responding to the Cry of the Earth and the Poor-

Towards an Integral Ecology

The Papal Encyclical \& the Role of Common but Differentiated

Responsibilities in the International Climate Change Negotiations Lavanya Rajamani 142

Energy, Consumption, and the Amorality of Energy Law

\section{Symposium on the Immunity of State Officials}

Introduction to Symposium: Immunity of State Officials from Foreign 
Criminal Jurisdiction: Comments on the International Law

Commission's Draft Articles Ingrid B. Wuerth

153

Foreign Official Immunity in the International Law Commission:

The Meanings of "Official Capacity" William S. Dodge 156

Horizontal Enforcement and the ILC's Proposed Draft Articles on the

Immunity of State Officials from Foreign Criminal Jurisdiction

Chimène I. Keitner

161

An "International Crime" Exception to the Immunity of State

Officials from Foreign Criminal Jurisdiction: Not Currently, Not Likely Roger O'Keefe

\section{Symposium on Alan O. Sykes}

Introduction to Symposium on Alan O. Sykes, "Economic "Necessity in International Law" Gregory Shaffer

Advancing Doctrine through Devil's Advocacy: A Response to

\begin{tabular}{c} 
Alan O. Sykes \\
On the Necessity of Necessity Measures: Alvarez-Jimenez \\
\hline
\end{tabular}

Anne van Aaken

Symposium on the International Legal Obligation to Criminalize Marital Rape Introduction to Symposium on the International Legal Obligation to

Criminalize Marital Rape Catherine Powell \& Carlos M. Vázquez

Criminalizing Sexual Violence against Women in Intimate

Relationships: State Obligations under Human Rights Law

Melanie Randall \& Vasanthi Venkatesh

Marital Rape, Consent, and Human Rights: Comment on "Criminalizing

Sexual Violence against Women in Intimate Relationships" Robin West

197

Considering the Role of the State: Comment on: "Criminalizing Sexual

Violence against Women in Intimate Relationships" Julie Goldscheid 202

Introduction to Continuation of Symposium on the International

Legal Obligation to Criminalize Marital Rape

Catherine Powell \& Carlos M. Vázquez

"If You Buy a Cup, Why Would You Not Use It?" Marital Rape:

The Acceptable Face of Gender Based Violence $\quad$ Fareda Banda 321

Marital Rape: The Long Arch of Sexual Violence Against Women

and Girls

Michelle Goodwin 326

Does International Law Really Require the Criminalization of Marital Rape? Barbara Stark 332

Zero-Tolerance Comes to International Law

Why Sexual Assault in Intimate Relationships Must Be Criminalized as

Required by International Human Rights Law: A Response to the

Symposium Comments Melanie Randall \& Vasanthi Venkatesh

Symposium on International Indigenous Rights, Financial Decisions, and Local Policy 
Introduction to Symposium on International Indigenous Rights,

Financial Decisions, and Local Policy $\quad$ Dwight Newman 207

Western Australia's Remote Indigenous Communities: A Case against

Closures and a Call for New Governance $\quad$ Asta Hill 209

Indigenous Title and Its Contextual Economic Implications: Lessons for

International Law from Canada's Tsilhqot'in Decision

$\underline{\text { Indigenous Peoples, International Law, and Extractive Industry }}$

$$
\text { Dwight Newman } 215
$$

Ibironke T. Odumosu-Ayanu 220

\section{Symposium on Koh \& Buchwald}

Introduction to Symposium on Koh \& Buchwald, "The Crime of

$$
\text { Aggression: The United States Perspective" } \quad \text { Dapo Akande } 226
$$

The International Criminal Court, Aggression, and Other Matters: A

$\begin{array}{ll}\text { Response to Koh and Buchwald } & \text { Nicholas Rostow } 230\end{array}$

Politics, the Rule of Law, and the Role of the Crime of Aggression,

A Response to Koh and Buchwald $\quad$ Tom Dannenbaum 235

Alea iacta est: The Kampala Amendment on the Crime of

Aggression post-2017: A Response to Koh and Buchwald

$$
\text { Andreas Zimmermann } 240
$$

Aggression, Affected States, and a Right to Participate: A Response to
$\underline{\text { Koh and Buchwald }}$
Sarah Williams

\section{Symposium on TWAIL Perspectives on ICL, IHL, and Intervention}

$\underline{\text { Introduction to Symposium }}$

James Thuo Gathii and Henry J. Richardson, III 252

Third World Approaches to International Criminal Law

Self-Referring to the International Criminal Court: A Continuation of

$$
\text { Asad G. Kiyani } 255
$$

War by Other Means $\quad$ Parvathi Menon 260

TWAIL and the "Unwilling or Unable" Doctrine, Continuities, and

$$
\text { Ruptures } \quad \text { Ntina Tzouvala } 266
$$

Islamic Contributions to International Humanitarian Law: Recalibrating

TWAIL Approaches for Existing Contributions and Legacies Corri Zoli

\section{Symposium on Joost Pauwelyn}

Introduction to Symposium on Joost Pauwelyn, "The Rule of Law without

the Rule of Lawyers? Why Investment Arbitrators are from Mars,

Trade Adjudicators are from Venus" Donald McRae

$\underline{\text { Panelists, Arbitrators, Judges: A Response to Joost Pauwelyn }}$

Judging from Venus: A Response to Joost Pauwelyn

Gabrielle Marceau, Catherine Quinn, and Juan Pablo Moya Hoyos 288

Apparent Dichotomies, Covert Similarities: A Response to Joost Pauwelyn

Catherine A. Rogers

The Rule of Law or the Perception of the Beholder? Why Investment 
Arbitrators are under Fire and Trade Adjudicators are not: A

Response to Joost Pauwelyn

Freya Baetens

302

Venus, Mars, and Brussels: Legitimacy and Dispute Settlement Culture

in Investment Law and WTO Law: A Response to Joost Pauwelyn

Robert Howse

309

The Relative Success of WTO Dispute Settlement and What Planet

Would the EU Investment Court System be on? A Rejoinder to

AJIL Unbound Comments

Joost Pauwelyn

316 